\title{
Privatisering av \\ Socialtjänstlagen - rättsliga villkor för att överlämna utredningar inom individ- och familjeomsorgen på entreprenad
}

ANNA HOLLANDER

Flera kommuner konkurrensutsätter idag verksamheter inom socialtjänsten. I Socialtiänstlagen (SoL) regleras förutsättningar för att överlämna uppgifter på entreprenad. I artikeln tecknas en bakgrund till de ökade kraven på privatisering av offentliga verksamheter. Lagregelns innehåll analyseras. Genom ett konkret exempel redovisas några av de tolknings - och tillämpningsproblem som aktualiseras $i$ fallet. ${ }^{1}$

\section{Inledning}

Välfärdspolitiken har under senare år starkt influerats av marknadsekonomiska modeller och privata lösningar. Omdefiniering av

Anna Hollander är professor i rättsvetenskap vid institutionen för socialt arbete, Stockholms universitet.
\end{abstract}

den offentliga sektorns roll har genomförts bl.a. genom delegering, avinstitutionalisering och förändringar av betalningssystem (Trydegård 2001, Svedberg Nilsson 2000,

1 Författaren har i en tidigare artikel behandlat juridiska problem vid privatisering av utredningsprocessen inom socialtjänsten (Hollander \& Madell 2003). 
Salonen-Soulié 1991). Andra privatiseringsformer som används är mindre hierarkiska organisationsformer men också försök med tydligare styrnings- och kontrollmekanismer som finns inom den offentliga förvaltningen själv (Tuori 2003). Konkurrensutsättning av socialtjänsten är en del av denna utveckling och Socialtjänstlagen (SoL) ändrades den 1 januari 1993 med det uttryckliga syftet att stimulera kommunerna att utsätta sin verksamhet för konkurrens och därmed öka förutsättningarna för ett effektivare utnyttjande av de resurser som samhället som helhet förfogar över (prop.1992/93:43, Thunved 1993, Hollander \& Madell 2003). Både de politiska och juridiska frågorna är omdiskuterade och det råder delade meningar om hur lagen skall tolkas.

Utvecklingen har inneburit att olika entreprenadverksamheter ökat i kommunerna och privata aktörer har fått en mer framskjuten roll när det gäller både produktion och finansiering av olika servicetjänster i kommunerna (Socialstyrelsen 2004). Med entreprenad avses sådan verksamhet som utförs av andra producenter än kommunens och landstingens egna organ. Det saknas dock en enhetlig terminologi (Riberdahl 1985). Privatisering i detta sammanhang innebär oftast att kommunen har kvar sitt huvudmannaansvar för att kommuninnevånarna skall få del av en viss tjänst men överlåter åt någon annan att sköta själva produktionen.

Syftet med den här artikeln är främst att beskriva ändringen av SoL 4 § (nuvarande SoL 2 kap.5 §) som genomfördes 1993 för att skapa förutsättningar för att lägga ut kommunal verksamhet på entreprenad till privaträttsliga subjekt. Det är de rättsliga villkoren för att överlämna utredningsfunktionen, inom främst individ- och familjeomsorgen, till annan privat utförare som analyseras. Begreppen förvaltningsuppgift och myndighetsutövning är grundläggande i lagtexten och analyseras särskilt. Genom ett konkret exempel, Stockholms kommuns projekt "Socialtjänst på entreprenad» som rättsligt har prövats av Länsrätten i Stockholms län, redovisas de tolknings- och tilllämpningsfrågor som aktualiserats i domen. Fallet har inte prövats i högre instans så rättspraxis saknas. JO har yttrat sig över liknade fall och ett sådant yttrande av JO redovisas. De frågeställningar jag försöker besvara är följande:

Vilka rättsliga problem skapar privatisering av socialtjänsten som offentlig verksamhet? Kan de krav på rättskydd och rättssäkerhet som gäller inom offentlig verksamhet garanteras medborgarna om utredningsverksamheten inom socialtjänsten lämnas till privata entreprenörer? Är socialtjänsten en offentlig verksamhet som förutsätter att särskilda villkor för insyn och kontroll måste kunna garanteras för att olika funktioner skall kunna privatiseras?

Ett rättsvetenskapligt perspektiv om hur yttre förhållanden påverkar rättsutvecklingen ligger till grund för framställningen. Internt påverkar rättsvetenskapen tolkningen av den aktuella lagregeln i SoL genom att den traditionella juridiska metoden används (Tolonen 2003, Alexius Borgström \& Hollander 2004). Som en bakgrund till samhällsutvecklingen ges en kortfattad beskrivning av kommunernas roll i välfärdspolitiken med fokus på olika lagstiftningsstrategier som instrument för 
statlig styrning och kontroll. Avsnitten om rättsstat, välfärdsstat, privat, offentlig verksamhet samt privat och offentlig rätt används för att belysa olika perspektiv på staten och rättens roll i samhällsutvecklingen. Några grundläggande principer för privat och offentlig rätt används som analysverktyg för att tolka de rättsliga konflikter som kommer till uttryck i länsrättens dom genom privatisering av utredningsverksamheten inom socialtjänstens individ- och familjeomsorg.

Juridisk metod används för beskrivningen av lagregelns innehåll och syfte samt för analysen av centrala begrepp. Det består av ett internt juridiskt perspektiv som innebär analys av rättskällor som lagtexter, propositioner och doktrin för att klarlägga lagstiftarens ställningstaganden och argumentation. För att svara på frågeställningarna används både det externa och det interna juridiska perspektivet. Artikeln avslutas med en diskussion om socialtjänstens roll i den offentliga verksamheten.

\section{Kommunerna och välfärden}

Kommunerna i Sverige har, historiskt sett, haft huvudansvaret för många offentliga åtagande inom välfärdsområdet (Vahlne Westerhäll 2002, Wallentin 1987). Kommunerna har tagit över vård och service på allt fler områden som tidigare varit familjens eller statens ansvarsområden, t.ex. insatser för barn, äldre, funktionshindrade och psykiskt sjuka. I takt med välfärdsstatens utbyggnad har den kommunala sektorn vuxit i omfång och betydelse (Bergmark 2001). Den specialreglerade, obligatoriska kommunala verksamheten har ökat på bekostnad av den fakultativa. Prioriteringen av den kommunala verksamheten har på så sätt gjorts av staten. Kommunerna protesterar mot detta bl.a. genom att inte uppfylla de rättsliga krav som lagstiftningen ställer (Hollander 1995, Lundin 2003). Det är uppenbart att kommunalt ansvarstagande för nationella socialpolitiska målsättningar skapar problem. Det kommunala självstyret minskar då kommunerna åläggs ytterligare uppgifter.

Utvecklingen har rättsligt inneburit en förändring av lagstiftningens materiella innehåll. Målstyrning genom s.k. ramlagstiftning, är SoL ett exempel på. Konkret reglering av lagstiftningens innehåll, omfattning och syfte har införts på andra områden. Lagen (1993:387) om stöd och service till vissa funktionshindrade (LSS) och införande av en riksnorm för socialbidraget är exempel på sådana preciseringar. Som socialpolitisk strategi används lagstiftning flitigt som statligt styrmedel. Det är dock inte helt enkelt att avgöra vilken betydelse lagstiftningen och olika lagstiftningsstrategier har för medborgarnas välfärd eller för kommunernas möjligheter att fördela sina resurser på ett effektivt sätt (Hetzler 1984, Hollander 1995, Åström 2000).

Ramlagstiftning som styrmedel ger större utrymme för att anpassa lagstiftningen till kommunernas lokala förutsättningar och villkor än konkret lagstiftning. Konkret lagstiftning har motiverats av rättssäkerhetsskäl. Konkreta lagar anses minska utrymmet för alternativa tolkningar och hela utredningsprocessen förutsätts bli tydligare och mer förutsebar för den enskilde. I praktiken försöker kommunerna kringgå 
lagstiftningen oavsett lagstiftningsstrategi och de demokratiska principer som skall vara utgångspunkten för den offentliga verksamheten har delvis satts ur spel (Hollander 1995).

I vilken mån utvecklingen inneburit ökad makt, handlingsfrihet och självständighet för kommunerna är också omdiskuterat (Bergmark 2001, Åström 2000). Kommittén Välfärdsbokslut har granskat välfärdens förändringar under 1990-talet och välfärdssektorn analyseras i frågor om förhållandet mellan stat och kommun samt förekomst av olika utförare av välfärdstjänster (Socialdepartementets kommitté direktiv 1999:7). Beskrivningen visar på en komplex utveckling, där 1990-talet innehåller händelser som såväl ökar som minskar den kommunala handlingsfriheten (Bergmark 2001). De viktigaste decentraliseringsbesluten togs samtidigt med en internationell och nationell ekonomisk kris med krav på begränsningar av den offentliga sektorn. Två reformer framhålls som särskilt viktiga i det sammanhanget, den ena är införandet av den nya Kommunallagen (KL). Kommunerna fick med den större utrymme för att självständigt utforma sin interna organisation. Den andra reformen är systemskiftet från öronmärkta till generella statsbidrag. Detta innebar att kommunerna själva kunde påverka och fördela bidragen (a.a.). I vilken mån det kom att leda till ökad kommunal demokrati i betydelsen att kommunmedborgarnas inflytande ökade eller att deras behov bättre kunde tillgodoses har inte studerats. Resursfrågorna dominerar kommunernas konflikter med staten. De generella statsbidragen har under senare år kompletterats med åtskilliga specialdestinerade bidrag. Staten försöker på olika sätt att förhindra att kommunen säljer allmänna sjukhus, allmännyttiga bostadsföretag m.m. i syfte att skaffa sig ökade inkomster (Thorngren 2004). Kommunerna uppmanas istället att ta ett fastare grepp över planeringen av den sociala servicen. Det betonas allt oftare i statens granskningar av kommunernas verksamhet, som nu duggar tätt (Stockholms Stads revisionskontor 2004).

Privatisering av offentliga rättsligt reglerade verksamheter genom konkurrens är en ny strategi som motiveras, av staten, för att effektivisera och förbättra dels de ekonomiska villkoren för den offentliga verksamheten dels för att bättre tillgodose medborgarnas behov (prop. 1992/93:43, Thunved 1993). Konkurrens ska, enligt lagstiftaren, kunna användas både inom den egna offentliga verksamheten och genom att överlämna offentliga förvaltningsuppgifter på privata subjekt som aktiebolag, föreningar eller enskilda (a.a.).

\section{Rättsstat - Välfärdsstat}

Hur den offentliga verksamheten ska regleras och organiseras är en grundläggande fråga i sammanhanget. Både historiskt, politiskt och rättsligt har det funnits en omfattande debatt om statens roll, särskilt om förhållandet mellan rätt och politik. Skall tyngdpunkten läggas på begreppet rätt eller på stat? Statens makt formas och utövas genom juridik, politik och ekonomi (Petersson 1996, Vahlne Westerhäll 2002). Den debatten har åter blivit aktuell och många viktiga rättsliga inlägg har publicerats (Gustavsson 2002, Hydén 2002, Madell 2003, 
Mannelqvist 2003, Tolonen 2003, Vahlne Westerhäll 2002). Rättsstaten brukar definieras med fokus på formell, rationell rätt (Tuori 2003). Rättsstatstänkandet utmärks av kravet på maktdelning. De offentliga myndigheternas handlingsutrymme regleras genom mer eller mindre preciserade handlingsregler. Statsmaktens position definieras genom kompetensregler inom vilka staten har behörighet att fatta beslut i förhållande till medborgarna. Genom rättsstaten införs på så sätt ett juridiskt moment i den politiska beslutsprocessen. Offentligrättsliga förhållanden är hierarkiska maktrelationer som i typiska fall uppstår genom maktsubjektens (myndigheternas) ensidiga beslut till skillnad mot privaträttsliga förhållanden mellan i princip jämlika rättssubjekt och som i typiska fall ingås genom dessa subjekts frivilliga rättshandlingar (Tuori 2003).

Gemensamt för olika rättsstatsteorier är två grundläggande krav. För det första skall enskilda medborgare garanteras rättsligt skydd, privatautonomi, i förhållande till staten (rättsskydd). För det andra får den offentliga förvaltningen ingripa i den enskildes rättsliga position endast genom juridisk behörighet samt inom gränser som beslutas av rätten (legalitet och rättssäkerhet). Socialtjänstlagens reglering och konstruktion av behörigheten att utreda ärenden är det rättsliga moment som ska analyseras närmare. Den offentliga förvaltningens lagbundenhet kan sägas utgöra grunden för den moderna rättsstaten (Petersson 1996, Tuori 2003). Rättsstatsidén går ut på att staten med hjälp av rättsordningen skall skydda den enskilde individen mot statens missbruk av rättsordningen. Staten skall, med andra ord, skydda individen mot staten själv. Detta förhållande är rättsstatens paradox. Den utgör rättsstatsideologins allvarligaste problem (Frändberg 1996).

Begreppet välfärdsstat används allmänt i internationell litteratur. Både begreppet stat och begreppet välfärd används i många betydelser av såväl normativ som beskrivande karaktär beroende på om betoningen läggs på begreppet välfärd eller stat. (Salonen-Soulié 1991). Välfärdsstaten brukar definieras med fokus på materiell, rationell rätt (Tuori 2003, Vahlne Westerhäll 2002). Med materiell rätt avses främst innehållet i rätten mer än formerna för densamma. Begreppet välfärdsstat kan beskrivas som en stat där staten har tagit som sin uppgift att svara för att garantera en minimilevnadsstandard för medborgarna genom socialpolitiska medel. Målsättningen demokrati, frihet och social välfärd för medborgarna och rättsstatens krav på rättssäkerhet och maktdelning är centrala också i välfärdsstaten (Mikkola 1988, Petersson 1996). Statens roll har i välfärdsstaten blivit mer omfattande än i den traditionella rättsstaten. Statens makt uttrycks i indirekta termer och makt i människors sociala samverkan har tonats ner och beskrivs $i$ termer av samverkan (Frändberg 1996, prop. 1979/80:1). Detta skapar problem för rättsstatsidan i välfärdsstaten för alla offentliga funktioner t.ex. i utredningsprocessen. Under 1990talet ändrades delvis den politiska uppfattningen om statens roll i välfärdspolitiken även om de grundläggande målsättningarna bibehölls. Den enskilde medborgarens rätt tonades ner och ersattes med ett tydligare skyldighetstänkande (Vahlne Westerhäll 2002). 
Rättsstaten och välfärdsstaten kan uppfattas och beskrivs både som olika stadier i den moderna rättens utveckling och som begrepp med olika mål (Vahlne Westerhäll 2002, Tuori 2003). Välfärdsstaten fokuserar på uppgifter inom det socialpolitiska området som ett materiellt mål. Rättsstaten beaktar främst former och procedurer för det offentliga beslutsfattandet. Det behöver inte vara en motsättning mellan rättsstatens och välfärdsstatens principer. Kritiken mot välfärdsstatens/rättsstatens byråkratiska och kontrollerande funktioner är, som nämnts, viktiga argument för krav på privatisering av offentlig verksamhet, ett reformarbete som pågår för att förändra och framförallt begränsa statliga strukturer och organisationer (Tuori 2003). Försvaret av de rättsliga principerna i välfärdsstaten motiveras främst av rättssäkerhetsskäl. Statens makt, befogenhet och behörighet att ingripa i människors liv, måste regleras i lag och framförallt kunna kontrolleras av medborgarna.

Staten försöker gå kommunerna tillmötes i frågan om självbestämmande genom att möjliggöra konkurrens även inom den specialreglerade kommunala verksamheten (prop. 1992/93:43). Hur de rättsstatliga och välfärdsstatliga principerna skall kunna tillgodoses i det sammanhanget är en grundläggande fråga för lagstiftaren att lösa.

\section{Privat rätt och offentlig rätt}

Indelningen $\mathrm{i}$ »det offentliga och det privata» och mellan offentlig och privat rätt är frågor som under lång tid diskuterats inom juridiken (Madell 1998, Tuori 2003). Termerna privaträtt och offentligrätt förutsätter att det, för den privata respektive offentliga sektorn, finns olika komplex av rättsregler (Madell 1998). Gränsen mellan de olika rättsområdena är oklar och det är svårt att klarlägga likheter och skillnader mellan olika funktioner som finns inom både privat och offentlig verksamhet t.ex. produktion, finansiering, ledning, planering, utredning, tillsyn och kontroll, beslutsfattande och ansvar (Sandgren 1993). Om funktionerna uppfattas vara självständiga i förhållande till varandra eller ses som delar av en helhet är av betydelse när bedömning ska göras av vilka områden som kan konkurrensutsättas (a.a.).

I den privata sektorn utgörs aktörerna $i$ första hand av enskilda fysiska eller juridiska personer, dvs. individer, bolag, föreningar, stiftelser, samfälligheter m.fl. civilrättsliga subjekt. Det privata området präglas av principerna om privat äganderätt och avtalsfrihet, som anses utgöra viktiga beståndsdelar i markandsekonomin i egenskap av rättsliga instrument som förenar de olika rättsliga aktörerna på marknaden. (Hollander \& Madell 2003). Syftet med den rättsliga regleringen är att lösa konflikter som parterna inte själva kan finna lösningen på genom avtal eller andra överenskommelser.

Det privata är inte enbart ett ekonomiskt system definierat ur ett nationalekonomiskt perspektiv. Familjen, den ideella sektorn eller det civila samhället har lanserats som motbegrepp till den offentliga sektorn (Lundqvist 1998, Salonen-Soulié 1991, Svedberg 2001, Trädgårdh 1995). Förändringar i relationen stat - marknad - familj är centrala på många olika välfärdsområden. Kvinnoforskningen visar att familjeperspektivet utvidgats mot staten och mark- 
naden. I stället för familj används också begreppen hushåll, den informella sektorn och det civila samhället för att beskriva områden utanför den offentliga verksamheten (Burman \& Gunnarsson 2000, Svedberg 2001). Privatiseringen som begränsningar av offentlig verksamhet kan i det sammanhanget innebära att offentliga uppgifter och offentligt ansvar återförs till familjen, släkten eller till närstående. I Socialtjänstlagen finns olika exempel på detta t.ex. regeln om stöd till anhöriga i 5 kap. $10 \S$ SoL eller regeln i 6 kap $5 \S$ SoL som anger att när ett barn skall placeras utanför hemmet, skall i första hand övervägas om barnet kan tas emot av någon anhörig eller annan närstående (6 kap 5 § SoL; prop. 1996/97: 124).

Utifrån Regeringsformens (RF) kategorisering, avser uttrycket det offentliga eller det allmänna i första hand stat och kommun och de myndigheter som företräder dessa. Den offentliga verksamheten är en följd av den konstitutionella relationen, maktdelningen, mellan det allmänna och medborgarna. Av regeringsformen framgår att:

\section{"All offentlig makt i Sverige utgår frän folket och den offentliga makten utövas under lagarna" (RF 1:1)}

Den offentliga verksamheten är därför i principiellt hänseende artskild från privat verksamhet eftersom förhållandet mellan staten och kommunerna å den ena sidan och samhällsmedlemmarna å den andra är reglerad i grundlagen (Hollander \& Madell 2003). Den offentliga verksamheten har på så sätt också givits demokratisk legitimitet. Det som framförallt utmärker den demokratiska rättsstaten är, som nämnts, exis- tensen av fasta former och stabila institutionella strukturer för utövandet av offentlig makt (Eklund 2001).

Enligt en strikt uppdelning mellan den offentliga verksamheten - den statliga och kommunala organisationen - och det privata utgör den offentliga sektorn det område där det allmänna fattar beslut, avkunnar domar och vidtar andra åtgärder med rättsverkningar för enskilda rättssubjekt. Utifrån rätttens mål kan skillnaden mellan det privata och det offentliga uttryckas så att det utmärkande för den privata sektorn är individualistisk frihet, säkerhet och effektivitet, medan den offentliga verksamheten bygger på konstitutionella regler, demokratiska principer, kollektiv ordning och effektivitet(Madell 1998).

I den offentliga förvaltningen ställs olika mål mot varandra: ett formbundet, byråkratiska mål som har till uppgift att fatta formellt rättssäkra beslut, materiella välfärdsmål om att tillgodose enskildas behov på en viss nivå och ekonomiska mål med krav på effektivitet och kostnadsbesparingar. Effektivitetsmålet finns inom både privat och offentlig verksamhet och benämns också produktivitet. Det beskriver förhållandet mellan resurser och resultat. Verksamhetens innehåll och kvalitet blir därmed avgörande. Effektivitetskravet omfattar hela beslutsprocessen dvs. både insamlingen av fakta och omständigheter, bedömning och analysfasen och det slutliga beslutet. När det gäller sociala omsorger och tjänster har effektivitetstänkandet visat sig vara svårt att väga i förhållande till medborgerliga behov. Hur man finner en avvägning mellan ekonomisk nytta och medborgerliga sociala rättigheter är ett dilemma som både politiker, jurister, tjänstemän och enskilda medborgare allt oftare 
ställs inför (Hollander \& Madell 2003).

Rättssäkerhets- och demokratifrågorna har kommit på undantag i den offentliga verksamheten under 1990-talet. Detta kan i viss mån förklaras av att marknadens logik och krav på lönsamhet mer eller mindre mekaniskt införts i det offentliga systemet (Hollander \& Madell 2003). Det framgår också av att kommunerna på olika sätt medvetet underlåter att följa lagstiftningens krav och domstolarnas domar. Lagstiftning beskrivs, av kommunerna, som ett hot mot den kommunala demokratin (Hollander 1998, Lundin 2003). Konflikterna mellan staten och kommunerna kan dock inte enbart förklaras av ekonomiska motiv. De tyder också på att det finns andra strukturella konflikter. Det allmänna förväntas sträva åt samma håll som olika delar av samma verksamhet.

Den demokratidebatt som också finns inom den offentliga verksamheten handlar om ökat inflytande och delaktighet för medborgarna och om noggrannare offentlig tillsyn och kontroll. Debatten tycks dock pågå utan samröre med den ekonomiska huvudlinjen. Ideologiska motsättningar skymmer också de reella skillnader som finns mellan privat och offentlig verksamhet, mellan ekonomiska principer och demokratiska. Det råder också oenighet om hur de marknadsmässiga principerna skall tillämpas i praktiken (Lundqvist 1998).

Privatisering av offentligrättsliga uppgifter har sedan frågan aktualiserades på 1980-talet varit kontroversiell och det är vid en närmare granskning lätt att hitta exempel på hur juridiska argument ställs mot politiska och ekonomiska utgångspunkter utan närmare analyser (Thunved 1993).
De överväganden som ligger till grund för förändringar av socialtjänstlagen 1993 ger också uttryck för detta. ${ }^{2}$ Lagen och dess förarbeten avspeglar en värdemässig plattform som skall tolkas och tillämpas av både politiker, ämbetsmän/kvinnor , jurister och enskilda medborgare (prop.1992/93:43, Åström 2000).

\section{Villkor för att överlämna offentliga verksamheter på entreprenad}

Kommuner och landsting har, sedan tidigare, i viss utsträckning, haft rätt att använda privaträttsliga organ för sin verksamhet och det har också stöd i rättspraxis (Thunved 1993). Genom 1991 års kommunallag (KL) förtydligades kommunernas möjligheter att lämna över förvaltningsuppgifter till privaträttsliga organ. En grundläggande rättslig princip är att den verksamhet som överlämnas faller inom ramen för den kommunala kompetensen och att risken för kompetensöverskridanden vid verksamhetens utövande skall vara ringa. Ytterligare begränsningar gäller på de specialreglerade områdena. En kommunal angelägenhet får i princip inte överlåtas till ett särskilt rättssubjekt, om det i en författning har angivits att ett visst organ skall handha uppgiften (a.a.). Detta utesluter inte att vissa delar av en specialreglerad

2 Socialtjänstlagen (1980:620) trädde ikraft 1982. Lagen har ändrats många gånger sedan dess. År 2002 infördes en ny Socialtjänstlag (2001:453). Den nya lagen är kapitelindelad och språkligt moderniserad i förhållande till den tidigare lagen. 
uppgift kan bedrivas i privaträttsliga former som driftsfrågor eller verkställighetsuppgifter. En förvaltningsuppgift som innefattar myndighetsutövning får överlämnas till ett privaträttsligt subjekt bara om det finns särskilt lagstöd för det. Det följer av regeringsformen (RF) 11 kap. 6 §. Andra författningsbestämmelser innebär att verksamheten skall bedrivas i viss form. Även om det numera framgår tydligare av kommunallagen att kommuner kan lägga ut verksamhet som innebär myndighetsutövning på privaträttsliga subjekt, finns det en osäkerhet om hur långt möjligheterna sträcker sig och vilka funktioner det gäller. I SoL reglerades före 1993 att kommunens uppgifter inom socialtjänsten fullgörs av den eller de nämnder som kommunfullmäktige bestämmer (se nuvarande 2 kap. $4 \S$ SoL). Det anges vidare att vad som i SoL eller annan författning sägs om socialnämnd gäller i förekommande fall den eller de nämnder som utsetts för ändamålet. Bestämmelsen fick sin utformning i samband med riksdagens beslut om ändrad ansvarsfördelning inom äldreomsorgen (prop. 1990/91:14, prop. 1992/93:43).

\section{Ändringen av Socialtjänstlagen 1993}

Socialtjänstlagen tillfördes, genom ändringen 1993, ett nytt fjärde stycke i 4 § SoL (nuvarande SoL 2:5). Av lagtexten framgår:

"Kommunen fär sluta avtal med annan om att utföra kommunens uppgifter inom socialtjänsten. Genom ett sådant avtal fär kommunen tillhandahailla tjänster åt en annan kommun. Uppgifter som innefattar myndighetsutövning fär dock inte med stöd av denna bestämmelse överlämnas till ett bolag, en förening, en samfällighet, en stiftelse eller en enskild individ".

Kommunerna får sluta avtal med annan att utföra kommunens uppgifter inom socialtjänsten. Lagen är inte tvingande. Med annan, dvs. entreprenören, avses bolag, förening, samfällighet, stiftelse, enskild individ eller annan kommun. En begränsning som anges i propositionen är att entreprenören måste vara behörig att utföra uppgifterna på området (prop. 1992/93:43). När det gäller andra kommuner framhålls att en kommun endast i begränsad omfattning får utföra uppgifter som ligger inom en annan kommuns kompetensområde. Med detta avses att kommunens yttersta ansvar inte får överlåtas till någon annan (prop. 1992/93:43, nuvarande 2 kap 1 § SoL).

Ändring av SoL innebär att uppgiftsöverföringen förutsätts ske genom entreprenadavtal. Föremålet för ett entreprenadavtal är en motprestation. I motsats till vad som gäller vid tjänste- och anställningsavtal är att den som skall utföra arbetet, entreprenören, inte är anställd hos uppdragsgivaren (prop. 1992/93:43, Thunved 1993). Entreprenören uppbär inte lön för arbetet under viss tid hos en arbetsgivare, utan hon ska mot ersättning prestera ett visst resultat. Entreprenören är inte liksom arbetstagaren underordnad den för vilken arbetet utförs (myndigheten) och inte personligen beroende av denne. Hon eller han arbetar som självständig företagare (a.a.).

I paragrafen har intagits en begränsande regel enligt vilken en uppgift som innefattar myndighetsutövning inte får överlämnas till privaträttsligt subjekt med stöd av bestäm- 
melsen. Inom socialtjänsten förekommer många typiska exempel på myndighetsutövning som alltså inte utan lagstöd kan överlåtas på annan huvudman. I propositionen anges som exempel beslut om olika former av bistånd och stödåtgärder inom individ och familjeomsorgen. Ett annat exempel som nämns är tvångsåtgärder enligt LVU och LVM (prop.1992/93:43). Beslutsfattande i dessa frågor kan alltså inte läggas ut på entreprenad. Detsamma gäller socialnämndens uppgifter enligt Föräldrabalken (FB) i samband med fastställande av faderskap och underhåll till vissa barn. Administrationen bör däremot kunna överlåtas på någon annan. Med administration avses, enligt lagstiftaren, löneutbetalningar, fakturering m.m. Rådgivande och kurativa funktioner inom socialtjänsten innefattar inte myndighetsutövning och kan läggas ut på entreprenad (prop. 1992/93:43). I socialtjänstlagen regleras till exempel att hem för vård eller boende (HVB), efter tillstånd, kan drivas av enskild eller en sammanslutning (SoL 7 kap.1 §). Entreprenad kan förekomma både genom att driften av hemmet lämnas över till någon enskild och att socialnämnden avtalar med ett privat vårdhem om placering av personer. Det finns inte heller några hinder mot att förlägga vård enligt LVU till ett privat familjehem eller HVB. Även om vården innefattar myndighetsutövning finns det enligt 11 § LVU särskilt lagstöd för att lägga ut uppgiften för att bestämma om den unges förhållanden på en föreståndare för en privat institution. Avgörande är att socialtjänsten behåller det yttersta ansvaret för den enskildes vård. Det innebär att socialtjänsten har, uppföljningsansvar, tillsynsplikt (se 6 kap. SoL).
Begreppet myndighetsutövning är komplext och har skapat många tolknings- och tilllämpningsproblem i offentlig verksamhet.

\section{Offentlig förvaltning och begreppet förvaltningsuppgift}

Den närmare innebörden av begreppen förvaltningsuppgift, ärende, ärendehandläggning är inte helt enkla att identifiera och det har under lång tid varit omdebatterat i doktrinen (Hollander \& Madell 2003). Offentlig förvaltning används främst som ett funktionellt begrepp som syftar på en verksamhets art. Det gör att såväl formella myndigheter som formellt privaträttsliga subjekt kan innefattas i begreppet (Marcusson 1993). Även den närmare innebörden av förvaltningsuppgift är diffus. En offentlig förvaltningsuppgift skall kunna utföras av myndighet. En presumtion är att verksamheten är offentlig även om den handhas av enskild. Det allmänna utövar vidare någon form av styrning eller kontroll av verksamheten samt bidrar till finansieringen av verksamheten. Slutligen innebär uppgiften någon form av påverkan på medborgarna (a.a.).

Andra försök att ge en generell definition av begreppet offentlig förvaltning har gjorts bl.a. genom kopplingar till begrepp som offentlig makt och maktutövning. Med risk för att hemfalla till begreppsjurisprudens syns det nästan omöjligt att förankra en generell definition av begreppet offentlig förvaltning i tydliga kriterier. En vanlig metod är därför att karaktärisera de bestämmelser som styr det allmännas verksamhet som »offentligrättslig reglering" för att särskilja den från enskild verksamhet, 
som typiskt sett regleras av privaträttsliga regler (Warnling-Nerep 2002). Enligt RF 11:6 3:e st. avgränsar termen myndighetsutövning de fall där det behövs lagstöd för det allmännas befogenhet att överlämna vissa typer av förvaltningsuppgifter till enskilda rättssubjekt. I praktiken är därför möjligheterna till överlämnande vid t.ex. skattefrågor, tillstånd, socialförsäkringar och andra sociala bidragsformer begränsade och i vissa fall uteslutna (Marcusson 1993).

För att förvaltningsuppgiften skall kunna överlämnas krävs inte att det allmänna, enligt lag, är tvungen att utföra den själv. I de fall det allmänna, staten eller kommunen, valt att bedriva sin verksamhet i privaträttslig form t.ex. genom bolag eller stiftelse, räknas dessa inte som förvaltningsmyndigheter. Detta får bl.a. till konsekvens att det allmännas möjlighet till styrning minskar till förmån för företagsledningens dispositionsrätt. Motsvarande gäller i olika omfattning för reglerna om JO:s tillsyn, offentlighets principens tillämpning, möjligheterna till överklagande, de förvaltningsrättsliga reglerna om partsinsyn, beslutsmotivering samt inte minst medborgarnas rätt till insyn i verksamheten (Landelius 2002).

\section{Begreppet myndighetsutövning}

Även innebörden av begreppet myndighetsutövning är mycket omdiskuterad. Termen används såväl vid ärendehandläggning som faktiskt handlande där en myndighet ensidigt och med bindande verkan bestämmer något i förhållande till den enskilde (prop.
1972:5, Hellners \& Malmqvist 1999). Alla bestämmelser i förvaltningslagen (FL) gäller vid ärendehandläggning hos förvaltningsmyndigheter, men i flera lagrum ställs särskilda krav på handläggningen som avser myndighetsutövning (FL 14-18; 20, 21 och $26 \S \S)$. Myndighetsutövning används som ett kriterium för att avväga den enskildes behov av rättssäkerhet mot effektivitetskrav i myndigheternas verksamhet.

Möjligheten att ensidigt fatta beslut är ett framträdande drag vid myndighetsutövning. Det är inte enbart så att det allmänna ensidigt fattar beslut i större utsträckning än vad enskilda kan göra. Ensidig maktutövning är dock på vissa områden utmärkande för det allmännas relation till medborgarna. Det gäller t.ex. allmän ordning och säkerhet, byggnads- och säkerhetsskydd. Till följd av svårigheter att fastställa vad som utgör myndighetsutövning har en negativ metod börjat användas. Det är många gånger enklare att ange vad som inte utgör myndighetsutövning t.ex. informationsverksamhet, råd, rekommendationer dvs. situationer där en myndighet inte bestämmer något som binder den enskilde. Förankringen i offentligrättsliga normer samt att den enskildes personliga eller ekonomiska situation i väsentlig mån påverkas av den offentliga verksamheten, kan sägas vara avgörande kriterier för tolkningen av begreppet myndighetsutövning (Ragnemalm 1992, Hollander \& Madell 2003).

\section{Stockholms kommuns projekt - Socialtjänst på entreprenad}

Kommunstyrelsen i Stockholms stad beslu- 
tade den 23 februari 2000 att starta projektet "Socialtjänst på entreprenad" (Dnr 653/00). Syftet med projektet var att kartlägga vilka verksamheter/arbetsprocesser inom individ- och familjeomsorgen som kan upphandlas i konkurrens. Kartläggningen behandlade frågan om man förutom att konkurrensutsätta förebyggande och rådgivande arbete, verkställighet och uppföljning av beslut, också kunde konkurensutsätta vissa delar av utredningsarbetet (Statsledningskontoret 2000).

Kommunfullmäktige (borgerlig majoritet) beslutade den 19 mars 2001, att enligt kommunstyrelsens förslag godkänna kartläggningen av vilka verksamheter som kan konkurrensutsättas och uppmanade stadsdelsnämnderna och socialtjänstnämnden att i sina aktivitetsplaner inarbeta upphandling inom individ- och familjeomsorgen i enlighet med ärendet. Kommunstyrelsen fick i uppdrag att samordna gemensamma upphandlingar mellan stadsdelsnämnderna, att ge berörda nämnder $\mathrm{i}$ uppdrag att $\mathrm{i}$ avtalen med respektive entreprenörer reglera granskning och insyn i utförandet av utredningar m.m. Kommunstyrelsen fick också $\mathrm{i}$ uppdrag att tillhandahålla expertkompetens till medborgarna för granskning, hjälp och vägledning. En arbetsgrupp skulle tillsättas med uppgiften att utvärdera upphandlingar som gjordes det första halvåret $\mathrm{i}$ syfte att bevaka medborgarnas rättssäkerhet (a.a.).

Kommunfullmäktiges beslut överklagades, av ett antal kommunmedlemmar, till Länsrätten i Stockholms län. De ansåg det oförenligt med lagen att dela upp förvaltningsuppgifter inom individ- och familjeomsorgen på det sätt som skett i projektet.
Det överklagade beslutet upphävdes av Länsrätten (LR dom 2001-12-21; mål nr. 6565-01). Enligt Länsrättens dom ansågs det främmande, att i avsaknad av direkt stöd i lagtext, dela upp handläggningen av en förvaltningsuppgift inom individ- och familjeomsorgen på så sätt som skett i kartläggningen.

Kommunstyrelsen i Stockholms stad beslutade den 9 januari 2002 (Dnr. 557/01) att överklaga Länsrättens dom i Kammarrätten i Stockholm. Stockholms kommunfullmäktige hade givit Wiweka Warnling Nerep, professor i offentlig rätt vid Stockholms universitet, uppdraget att analysera Kommunfullmäktiges beslut med avseende på ett antal förvaltningsrättsliga och konstitutionella frågor. Av utlåtandet framgår att professor Warnling Nerep inte anser att Länsrätten har haft ett tillräckligt stöd i gällande författningar för sin bedömning att Stockholms kommuns beslut skulle vara olagligt enligt Kommunallagen (Warnling-Nerep 2002). Professor Warnling Nerep konstaterar sammanfattningsvis att Länsrätten har en sammanhållen syn på begreppet "förvaltningsuppgift" varvid handläggningen i dess helhet klassificeras som myndighetsutövning. Stockholms kommun däremot hävdar att handläggningen kan delas i många olika förvaltningsuppgifter och där en del utgör myndighetsutövning medan andra inte gör det. Stockholms kommuns tolkning får stöd av professor Warnling-Nerep. Detta rättsliga utlåtande bifogades Stockholms kommunstyrelses utvecklade grunder för prövningstillstånd i Kammarrätten tillsammans med ett rättsligt utlåtande från Svenska kommunförbundet (Kammarrät- 
ten i Sthlm. mål nr. 287-2002). Efter valet, hösten 2002, fick Stockholms stad ny politisk (socialdemokratisk) majoritet. Överklagandet återkallades och Länsrättens dom vann laga kraft. De omtvistade juridiska frågorna kom alltså aldrig att prövas i Kammarrätten eller i Regeringsrätten.

\section{JO2001/02 s.250}

Frågan om kommunen får överlämna delar av socialtjänstens utredningsverksamhet till privata bolag har även anmälts till JO av flera kommunmedlemmar i olika delar av landet. Under JO:s handläggning av frågan fattade kommunfullmäktige i Stockholm sitt beslut. JO granskade dock inte Stockholms kommunfullmäktiges beslut med anledning av att det var föremål för prövning i Länsrätten. JO:s yttrande avser ett antal andra kommuner. JO hänvisar i sitt yttrande till Regeringsformen (RF) 11:6 3: e st. Det framgår där, som nämnts, att förvaltningsuppgift som innefattar myndighetsutövning får överlämnas till privata rättssubjekt; bolag, förening, samfällighet, stiftelse eller till enskild individ endast med stöd av lag. Samma innebörd återfinns i lagregeln 2:5 SoL. Den centrala juridiska frågan, som JO formulerar den, är om utredningar ingår i begreppet myndighetsutövning. Enligt JO:s mening kan bestämmelsen inte ges annan innebörd än att den tar sikte på hela handläggningen av ett ärende. Beredning av och beslut $\mathrm{i}$ ärendet måste $\mathrm{i}$ princip anses utgöra oskiljaktiga delar av en och samma förvaltningsuppgift. Om ärendet (förvaltningsuppgiften) innefattar myndighetsutövning hos socialnämnden kan nämnden enligt 11:6 tredje st. RF inte överlämna handläggningen av det till ett privaträttsligt subjekt om det inte finns stöd för det i lag. När det gäller socialtjänsten finns inte något sådant lagstöd, ansåg JO. JO kom alltså till samma slutsats som Länsrätten i Stockholms län.

JO gör en åtskillnad mellan utredningar $\mathrm{i}$ ärenden som rör myndighetsutövning och utredningar som innefattar myndighetsutövning. I det förra fallet ansåg JO att hinder för att överlämna utredningar till privaträttsliga subjekt fanns enligt dåvarande $50 \S$ SoL, nuvarande 11:1 SoL. Skälet var att det finns ett nära samband mellan utredningen i dessa fall och det ansvar som socialnämnden har när det gäller att tillgodose den enskildes behov i olika avseenden. JO framhåller vidare att om utredningar läggs ut på entreprenad, inom det socialrättsliga området, skulle detta kunna få konsekvenser bl.a. avseende rättssäkerhet, dokumentation, sekretess, partsinsyn, jäv, tjänstefelsansvar och tillsyn, eftersom dessa regler helt eller delvis skulle kunna sättas ur spel. JO: s slutsats blev att socialnämnd inte får överlämna utredningar som rör myndighetsutövning till privaträttsligt subjekt. Det finns dessutom hinder i lagen för sådana överlämnanden där socialnämndens roll är att yttra sig till en annan myndighet.

För förvaltningsuppgifter som inte rör, men innefattar myndighetsutövning, framhåller $\mathrm{JO}$, att yttranden som socialnämnden är skyldig att göra enligt lag eller annan författning inte heller kan lämnas på entreprenad, men också att förbudet omfattar den utredning som föregår yttrandet t.ex. vårdnadsutredningar enligt 6 kap.19 § Föräldrabalken (FB).

JO anser dock att det finns ett visst 
utrymme för socialnämnden att använda osjälvständiga uppdragstagare för att göra utredningar inom socialtjänsten. Enligt 3 kap $3 \S$ SoL anges att det för utförandet av socialnämndens uppgifter skall finnas personal med lämplig utbildning och erfarenhet. Bestämmelsen är allmänt utformad. Den syftar dock till att framhålla betydelsen av att upprätthålla en hög kompetens inom socialtjänsten och att det - med hänsyn till socialtjänstens vitt skilda uppgifter - skall finnas personal med olika bakgrund och erfarenhet. Med personal avses personer som är anställda av kommunen (prop. 1996/97:124). En anställning gäller enligt huvudregeln tillsvidare. En möjlighet finns att tidsbegränsa en anställning enligt $5 \S$ lagen (1982:80) om anställningsskydd vid bl.a. tillfällig arbetsanhopning. En kommun anses också, liksom andra arbetsgivare, ha möjlighet att anlita uppdragstagare för att utföra en viss arbetsuppgift. Det finns olika typer av uppdragstagare. En del har en mycket lös anknytning till sin uppdragsgivare och kan jämföras med entreprenörer medan andra kan vara så nära knutna till arbetsgivarens verksamhet att de kan betraktas som införlivade i organisationen. Som regel råder det inte någon osäkerhet om en person är arbetstagare eller uppdragstagare. I detta sammanhang är det, enligt JO, snarast gränsdragningen mellan olika slag av uppdragstagare som är av intresse bl.a. i sekretesshänseende. Sekretesslagen är tillämplig på uppdragstagare hos myndighet som har sådan anknytning till myndigheten att de kan sägas delta i myndighetens verksamhet. Med myndighetens verksamhet avses myndighetens egen verksamhet, den som kan utläsas av myndig- hetens instruktion eller annan författning (prop.1979/80:1, prop.1981/82:168). Som exempel på uppdragstagare som omfattas av sekretesslagen angavs i propositionen, som här är av särskilt intresse, kontaktpersoner inom socialtjänsten, personer som ställt sig till socialvårdens förfogande med s.k. kontrakterade familjehem, konsulter av olika slag och tolkar (a.a.). Enligt JO:s mening finns det utrymme för socialnämnderna att utifrån offentligrättsliga aspekter använda s.k. beroende eller osjälvständiga uppdragstagare för att utföra utredningar inom socialtjänsten därför att de kan sägas delta i myndighetens verksamhet.

Sammanfattningsvis kan konstateras att frågan om privatisering på socialtjänstlagens område, särskilt utredningsfunktionen, har besvarats negativt av Länsrätten i Stockholm och av JO. Det saknas prejudikat som kan vägleda utvecklingen på detta expansiva och kontroversiella område. Professor Warnling Nerep ifrågasätter både JO:s och Länsrättens tolkning och ställer frågan i sitt yttrande om det finns ett helt eget myndighetsbegrepp inom socialtjänstområdet. Om så vore fallet skulle det innebära att striktare bedömningar och begränsningar skall göras inom detta område där rättsskydd och rättssäkerhet för enskilda bör tillmätas mycket stor betydelse på grund av att de beslut som fattas oftast har stor betydelse för enskilda (Warnling Nerep 2002).

\section{Avslutande diskussion}

Det uppstår, som visats, många problem när socialtjänsten konkurrensutsätts. Den 
offentliga verksamhetens särdrag är några av de viktigaste förklaringarna till detta. Teoretiskt betonas demokrati- och rättssäkerhetsprinciperna men också kraven på effektivare organisation och beslutsprocess. Också privat verksamhet kräver formella procedurer och kvalitativa krav. Det saknas kunskaper om hur beslut i offentlig förvaltning - inom socialtjänsten - egentligen fattas. Vi vet däremot att många beslut motiveras med hänsyn till kommunens bristande resurser och inte i förhållande till enskildas behov (Hollander 1998, Socialstyrelsen 2002). Socialtjänstens speciella villkor är att enskilda ofta befinner sig i en utsatt situation och är mer eller mindre beroende av att myndigheterna kan företräda deras intressen och att förutsättningar för bistånd utreds på ett professionellt och rättssäkert sätt. Den enskildes valsituation är många gånger begränsad. Den enskilde kan avstå eller avböja att en utredning genomförs men då kan inte behovet av insatser bedömas. Myndigheten har tolkningsföreträde, vilket innebär att myndigheten avgör vilka fakta och omständigheter som krävs för att genomföra en tillförlitlig utredning och för att kunna bedöma den enskildes behov. Denna asymmetriska relation mellan myndighet och enskild är det främsta motivet för att de krav som ställs på beslutsfattandet i kommunerna är tydliga och ger förutsättningar för offentlig insyn och kontroll. Offentligt beslutsfattande - myndighetsutövning - handlar både om de funktioner som leder fram till ett beslut och konsekvenserna av själva beslutet. Att dela upp utredningsprocessen inom socialtjänstens individ- och familjeomsorg $\mathrm{i}$ olika funktioner, menar jag, försvagar snarare än stärker förutsättningarna för en professionell, rättssäker och demokratisk offentlig beslutsprocess. Ur ett professionellt perspektiv betonas också en helhetssyn på utredningsprocessen. Faktainsamlingsfasen är i det sammanhanget lika viktig som bedömnings- och beslutsfasen (Jakobsson Öhrn 2005).

Det är för enkelt att se privatiseringen som ett hot mot den offentliga sociala välfärden. Privatiseringen kan ses som en reaktion mot den expanderande och i många situationer dåligt fungerande offentliga förvaltningen. Av fördelningspolitiska eller sociala rättviseskäl kan ingen helt förespråka marknaden. Vilka uppgifter inom socialtjänsten som kan privatiseras måste bedömas i sin rättliga kontext. Ett så svårtolkat begrepp som myndighetsutövning ger utrymme för olika tolkningar och villkor för privatisering på olika områden. 


\section{Referenser}

Alexius Borgström, Katarina \& Hollander, Anna (2004) "Rättsvetenskapliga metoder». I Larsson, Sam, Lilja, John och Mannheimer, Katarina (red). Forskningsmetoder i Socialt Arbete. Lund: Studentlitteratur.

Bergmark, Åke (2001) „Den lokala välfärdsstaten? Decentraliseringstrender under 1990-talet». I Szebehely, M. (red.) Välfärdstiänster $i$ omvandling. Antologi/Kommittén Välfärdsbokslut/ SOU 2001:52.

Burman, Maud \& Gunnarsson, Åsa (2000) Familjeföreställningar. Om familiens betydelse inom juridik, ekonomi och forskning. Uppsala: Iustus förlag.

Eklund, Claes (2001) "Behovet av rättslig tillsyn över offentlig verksamhet». Juridisk tidskrift 2001-02 s. 961-974.

Frändberg, Åke (1996) „Begreppet rättsstat». I Stertzel, Fredrik (red). Rättsstaten - Rätt, Politik och Moral. Rättsfondens skriftserie 31. Uppsala: Iustus förlag.

Gustafsson, Håkan (2002) Rättens polyvalens. En rättsvetenskaplig studie av sociala rättigheter och rättssäkerhet. Lund Studies in Sociology of Law. Lund: Lunds University.

Hellners, Tryggve \& Malmqvist, Bo (1999) Nya Förvaltningslagen med kommentarer. Stockholm: Publica.

Hetzler, Antoinette (1984) Rättens roll i socialpolitiken. Malmö: Liber förlag.

Hollander, Anna (1995) Rättighetslag i teori och praxis. Uppsala: Iustus förlag.

Hollander, Anna (1998) „Verkställighet av länsrättens domar och beslutu. I Bengtsson, H (red.) Politik, Lag och Praktik - implementering av 1994 års handikappreform. Lund: Studentlitteratur.

Hollander, Anna \& Madell, Tom (2003) „Socialtjänst på entreprenad«. Förvaltningsrättslig tidskrift nr.1 s.15-46.

Hydén, Håkan (2002) Normvetenskap. Lunds Studies in Sociology of law. Lund: Lunds universitet.

Jakobsson Öhrn, Harriet (2005) Berätta din sanning. (Diss). Pedagogiska institutionen. Stockholm: Stockholms universitet.
JO 2001/02 s.250.

Kammarrätten i Stockholm, målnr. 287-2002.

Kommunstyrelsen i Stockholms stad beslut 9 januari 2002 Dnr 557/01.

Landelius, Ann-Charlotte (2002) „Privaträttsliga subjekt inom socialtjänsten". I Vahlne Westerhäll. Lotta (red). Rättssäkerhetsfrågor inom socialrätten. Stockholm: Norstedts Juridik.

Lundin, Olle (2003) "Sanktionsavgifter inom Socialtjänstområdet - ett stort steg för lagstiftaren, ett litet steg för enskildas sociala rättigheter". I Förvaltningsrättslig tidskrift $\mathrm{nr}$.3 s. 465-478.

Lundqvist, Lennart (1998) Demokratins Väktare. Lund: Studentlitteratur.

Länsrätten i Stockholms län målnr. 6565-01 dom 2001-12-21.

Madell, Tom (1998) Det allmänna som avtalspart - särskilt avseende kommuns kompetens att ingå avtal samt avtalens rättsverkning. Stockholm: Norstedts Juridik.

Madell, Tom (2003) „Privatiseringen och den rättsvetenskapliga forskningen«. I Förvaltningsrättsliga tidskrift. nr 4. s. 583-594.

Mannelqvist, Ruth (2003) Samband i socialförsäk ringen. En rättsvetenskaplig studie av sambandet mellan förmåner och avgifter $i$ socialförsäkringen. Uppsala: Iustus förlag.

Mikkola, Matti (1988) „Sociallagstiftning och samhällelig förändring». I Tuori, Kaarlo (red.) Rättsdogmatikens alternativ. Helsingfors: Juridika.

Marcusson, Lena (1993) "Avtal mellan det allmänna och enskilda». I Sandgren, Claes (red.) Utvecklingslinjer inom avtalsrätten. Stockholm: Norstedts Juridik.

Petersson, Olof (1996) Rättsstaten. Frihet, rättssäkerhet och maktdelning $i$ dagens politik. Stockholm: Publica.

Proposition 1972:5 Förvaltningslagen

Proposition 1979/80:1 Om Socialtjänsten

Proposition 1979/80:2 Sekretesslagen

Proposition 1981/82:168 Vårdnad umgänge m.m.

Proposition 1990/91:14 Om ansvaret för service och vård till äldre och handikappade

Proposition 1992/93:43 Ökad konkurrens i kommunal verksamhet 
Proposition 1996/97:124 Ändring i socialtiänstlagen

Ragnemalm, Hans (1992) Förvaltningsprocessrättens grunder. Stockholm: Publica

Riberdahl, Curt (1985) „Privatisering, entreprenad eller kommunal driftu. I Förvaltningsrättslig Tidskriftnr 4-5 s. 137-176.

Salonen-Soulié, Ulla (1991) Välfärdsstatens socialservice under förändring. Privata alternativ i Danmark. Meddelanden från Ekonomiska statsvetenskapliga fakulteten vid Åbo akademi. Ser. A: 329 Åbo.l

Sandgren, Claes (1993) „Utvecklingstendenser inom avtalsrätten". I Sandgren, Claes (red.) Utvecklingslinjer inom avtalsrätten. Stockholm: Norstedts Juridik.

Socialstyrelsen (2004) Konkurrensutsättning och entreprenader inom äldreomsorgen. Utvecklingsläget 2003.

Statsledningskontoret (2000) 2000-06-05, Dnr. $653 / 00$

Stockholms stads revisionskontor (2004) Revisionsrapport Dnr 420/01-04

Svedberg Nilsson, Karin (2000) "Markandens decennium - gränsomfattande reformer i den offentliga sektorn under 1990-talet«. I Välfärd, vård och omsorg. Szebehely. Martha (red.) Antologi/Kommittén Välfärdsbokslut/SOU 2000:38

Svedberg, Lars (2001) "Spelar ideella och informella insatser någon roll för svensk välfärdı. I Szebehely, M (red.) Välfärdstjänster $i$ omvandling. Antologi/Kommittén Välfärdsbokslut/ SOU 2001:52

Thorngren, Håkan (2004) „Den kommunala självstyrelsen ur ett rättsligt perspektiv". I Förvaltningsrättslig tidskrift. Nr.1 s. 39-61.
Thunved, Anders (1993) Privatisering av socialtjänsten. Om rättssäkerheten för den enskilde. Stockholm: Publica

Tolonen, Juha (2003) „Rättsvetenskapens utveckling i Finland efter kriget». Retfaerd. Nordisk tidskrift for ret og samfund. Nr.3 s. 51 -62.

Trydegård, Gun-Britt (2001) „Välfärdstjänster till salu - privatisering och alternativa driftformer under 1990-talet». I Szebehely, Martha (red.) Välfärdstjänster $i$ omvandling. Antologi/Kommittén Välfärdsbokslut/2001:52

Trädgårdh, Lars (1995) „Svenskhet och Civilitet: Om dygd, kärlek och oberoende i svensk politisk kultur". I Trädgårdh, Lars (red). Civilt Samhälle kontra Offentlig sektor. Stockholm: SNS förlag.

Tuori, K (2003) „Har förvaltningsrätten en framtid». I Förvaltningsrättslig tidskrift. Nr 4 s. 553574.

Vahlne Westerhäll, Lotta (2002) Den starka statens fall. En rättsvetenskaplig studie av svensk social trygghet 1950-2000. Stockholm: Norstedts Juridik.

Wallentin, Hans (1987) Kring arbetslöshet och socialpolitik $i$ Sverige sedan 1700-talet. Idéutveckling. Högskolan i Östersund. Rapport 1987:8 Östersund.

Warnling Nerep, Wiweka (2002) Utlåtande angående konkurrensupphandling av viss verksamhet inom individ - och familjeomsorgen. Stockholms stad. Juridiska avdelningen.

Åström, Karsten (2000) „Förändringar och förskjutningar i välfärdens rättsliga reglering under 1990-taletw. ISzebeheley (red.) Välfärd vård och omsorg. Antologi/Kommittén Välfärdsbokslut. SOU 2000:38. 


\section{Summary}

\section{Privatization of the Social Services Act \\ Special legal conditions to pass investigations for social services on contract}

Many local governments in Sweden today leave parts of their various public responsibilities to private entrepreneurs. Welfare policies during the last few decades have been influenced by market-oriented solutions, aiming to do business, rather than public activities. Private solutions are used by changing the organizations, the decisionmaking process and charging systems. Privatization of the Social Services Act is part of this development. The law was changed in 1993 to stimulate local governments to use entrepreneurs more frequently than before.

The political and legal questions, though, are very much discussed and there are many different views about the interpretation of the Act. The political questions concern how society's goals of democracy and equality can be protected. The legal question concern how individual legal claims are handled and how legal security can be guaranteed.
The local social services system is part of a public system. Special demands, such as public observation and control, distinguish this system from private organizations. These conditions are difficult to protect when public activities are passed to private persons or organizations.

The social services support regulated by the Social Services Act is of importance for many people. They are often in an exposed position and dependent on how their needs are investigated. The investigation process concerns all the different stages that constitute the decision-making process and the consequences of the decision itself. Passing the investigation process to entrepreneurs will weaken both the individual's own control of the process and the public's control rather than strengthening a democratic public decision-making process that is of special importance in this public field. 